NBER WORKING PAPER SERIES

\title{
UPDATED NOTES ON THE \\ INTERINDUSTRY WAGE STRUCTURE
}

Steven G. Allen

Working Paper No. 4664

\section{NATIONAL BUREAU OF ECONOMIC RESEARCH 1050 Massachusetts Avenue \\ Cambridge, MA 02138 \\ February 1994}

This research was supported by National Science Foundation Grant No. SES-8707758 and North Carolina State University. I have received very helpful research assistance from Vivian Lamb and Jonathan Long. Daniel Hamermesh, William Dickens, Jean Helwege, David Blanchflower, Andrew Oswald, Robert Margo, Jack Wilson, Lee Craig and the participants of the Duke Labor Lunch have given me useful feedback. The data set compiled from the 1909 and 1947 Censuses of Manufacturing is available from the author upon request. This paper is part of NBER's research program in Labor Studies. Any opinions expressed are those of the author and not those of the National Bureau of Economic Research. 


\title{
UPDATED NOTES ON THE \\ INTERINDUSTRY WAGE STRUCTURE
}

\begin{abstract}
This paper documents and analyzes changes in the wage structure across manufacturing industries over the last one hundred years. Inter-industry differentials in wages are highly stable for production workers, but autocorrelation patterns for nonproduction workers are considerably weaker. Industry wage patterns are very similar for production and nonproduction workers today, but this has been true only since 1958 . Dispersion of wages across industries has shown varying trends over the last one hundred years, but has never in this century been higher than it is today. The variables that are most strongly correlated with wage growth are productivity growth, rising union density, rising capital intensity, and profit growth.
\end{abstract}

Steven G. Allen

Departments of Economics and Business Management

Box 7229

North Carolina State University

Raleigh, NC 27695-7229

and NBER 
The interindustry structure of wages has received unprecedented attention in recent years. There are large differentials in wages across industries, even after controlling for a broad range of worker and job characteristics, including fixed effects for individual workers.' This effect is uniform across occupations; middle managers and computer programmers enjoy the same wage premium as drill press operators and secretaries. Interindustry differentials also are stable over time.

This research has been cited as evidence of the inadequacy of simple competitive models and the wisdom of aiternative approaches such as efficiency wage or insider-outsider models. Critics counter with the argument that the wage differentials across industries reflect differences in labor quality that are unobservable to the person analyzing the data, but well known to workers and employers. ${ }^{2}$

The motivation behind this paper is that the odds of reaching agreement about the interpretations of these findings are low relative to the odds of reaching agreement about the basic patterns in the data. In the spirit of Slichter (1950), from whom I have partially borrowed the title of this paper, the purpose here is to "search for regularities in the wage structure" rather than to test specific theories.

The innovation here is the use of a century of data. This approach puts the evidence on both the stability and the determinants of the wage structure to a more demanding test. With the exception of Krueger and Summers (1987), the modem literature has produced no new evidence on the stability of wage differentials over periods of thirty years or more. All of the evidence on autocorrelation over such lengthy periods is restricted to production workers. This study examines earnings of nonproduction workers to learn not only about autocorrelation, but also about how the correlation with earnings of production workers has 
evolved. Most studies have defined stability in terms of autocorrelation; here the definition is expanded to include dispersion of wages across industries.

Almost all the recent work on the determinants of the interindustry wage structure has used a cross-sectional approach. This is problematic because many industry characteristics in cross sections are correlated with each other and with labor quality. The potential beauty of first differencing over a long enough time period is that changes in industry characteristics would exhibit more independent variation than levels and that the unobservables would be scotched entirely.

\section{Data}

The analysis focuses on the manufacturing sector. Data on wages by industry for the nonmanufacturing sector are not widely available before 1972 . Further, data on industry characteristics that could be useful for explaining changes in wage differentials remain scarce outside of manufacturing. ${ }^{3}$ To examine factors associated with changes in the interindustry wage structure, this study aralyzes the NBER Trade and Immigration data set and creates a special data set for 1909-1947. The 1910 Census of Manufacturing contained a special survey on the length of the usual work week across industries in 1909 that allows one to calculate average hourly earnings for production workers (payrolls divided by the product of average monthly employment, average weekly hours, and 52). Industries in this special survey were matched with the regular Census data for 1909, 1947 (101 industries), and 1982 (52 industries). The main advantage of the NBER data set is that it has comprehensive coverage of all 450 four-digit industries and reports the capital stock and a price deflator for 
each industry's output. The main advantage of the 1909-47 data is that the circumstances in that time period are quite different; most notably union density grew considerably over this period. Also, results for $1909-47$ permit replication of classic studies done by Dunlop (1948), Garbarino (1950), Ross and Goldner (1950), Meyers and Bowlby (1953), and Salter (1960).

\section{Autocorrelation for production workers}

Autocorrelation of the interindustry wage structure is widely accepted today as a stylized fact. This was not always the case, as indicated by the following passages quoted by Cullen (1956):

An examination of long-term changes in the wage structure shows conclusively that diverrity rather than uniformity has been its outstanding characteristic. ... On no basis and for an period is there revealed anything remotely resembling a uniform pattern of change. - Backman and Gainsbrugh (1948)

A study of Table 7 underlines the severe limitations to the view that inter-industry wage differentials are relatively constant over considerable periods of time. ... The simple fact is that the relative pasition of industries has been changing very rapidly over a period of time. - Dunlop (1948)

Slichter (1950) was most influential in changing professional opinion on this issue and continues to be cited prominently in every recent study of interindustry wage differentials. Slichter devoted three sentences and one table to show that the average hourly eamings of male unskilled labor in twenty manufacturing industries were highly correlated between 1923 and July 1946. His rank correlations ranged from 0.73 for the entire period to 0.89 for 1929 to 1939 .

Two-digit industries What would happen if someone replicated Slichter's results with more recent data or with other data sets that were not available at the time he did his study? 
Regressions of log wages for two-digit manufacturing industries in 1988 on their values in 1947 are reported in Panel A of Table 1 along with similar regressions for the first half of the century. The results are very unfavorable toward the hypothesis that the interindustry wage structure is stable. Of the four data sets examined, the Conference Board data set for 1914-1946 is the only case where there is a strong degree of autocorrelation. This is not a coincidence; Slichter used the same data set for a shorter period. In two of the other three cases, $\mathrm{R}^{2}$ is below 0.20 and in the third it is 0.40 , well below the value of 0.63 obtained for the Conference Board data.' The obvious implication, given the prevailing wisdom at the time Slichter wrote and the results in Table 1, is that if Slichter had used a different data set, the consensus still would be that inter-industry wage differentials are highly flexible.

Not quite. Correlation estimates are sensitive to outliers. Slichter used rank correlations, a method that ignores changes in the distance among various industries and assures that there are no outliers. The opposite problem arises with Pearson correlations if the outliers are in small industries. The low $\mathrm{R}^{2}$ values vanish when the observations are weighted by average employment, as shown in Panel B of Table $1 . R^{2}$ in the log equation jumps to 0.55 for the $1899-1953$ sample and to 0.44 in the $1947-1988$ sample.

Four-digit industries When the data are examined at the four-digit level of aggregation, the evidence indicates even greater stability in the interindustry wage structure. Between 1909 and 1947, an autoregression of log average hourly eamings for production workers has an $R^{2}$ of 0.550 ; between 1958 and $1984, R^{2}$ is 0.722 . This is a further indication that Slichter was correct about the interindustry wage structure, after all. ${ }^{6}$ At 
least half of the variation of wages at any point in time can be explained by the variation of wages forty or fifty years ago.

This still leaves room for substantial variation in the position of industries in the wage hierarchy. Between 1958 and 1984, one third of the four-digit industries in manufacturing moved up or down the wage hierarchy by two or more deciles; 81 moved up and 68 moved down. Given the longer time period, there is proportionally equal movement in the interindustry wage structure between 1909 and 1947, when only half of the industries stayed within a decile of their original position; 24 of 101 moved up by two or more decile, while 27 moved down.

The odds that an industry at the very bottom of the distribution will move up are much lower than the odds that an industry at the top will move down. Of the 45 industries in the bottom decile in 1958 , only four jumped above the ninth decile by 1984 and no industry advanced any higher than the seventh decile. In contrast, 10 to 15 industries from each of the top three decile moved down by two decile or more and 11 of these fell to the bottom half of the distribution.

Long-run comparisons There are 52 industries for which wages for production workers can be estimated for both 1909 and 1982 . The results for an employment-weighted regression are:

$$
\operatorname{Ln}(w 82)=\underset{(0.464)}{4.184}+\underset{(0.270)}{1.128} * \operatorname{Ln}(w 09) ; R^{2}=0.259
$$

The findings that the $\mathrm{R}^{2}$ is reasonably high and that the coefficient is not meaningfully different from one are phenomenal, given the century-long changes in technology and worker 
characteristics. There is some evidence of the type of self-correcting behavior that one would expect from competition (or regression to the mean?); the industries with the most rapid wage growth between 1909 and 1947 tend to have slower wage growth for 1947-82:

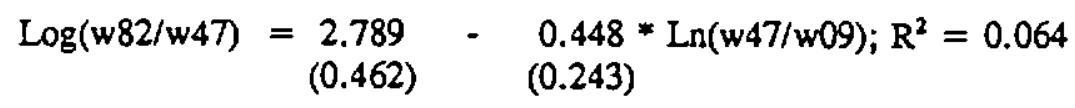

\section{Autocorrelation for nonproduction workers}

Even though the industrial waje structure for production workers is relatively stable and Dickens and Katz (1987b) have shown that industry differentials are highly correlated across occupations in 1983, the stability of inter-industry earnings differentials for nonproduction workers remains an open question because there is no evidence for these workers before the 1970s. Data at the two-digit level of aggregation are available since 1899 in the Census of Manufacturing. ${ }^{7}$ There is no autocorrelation in nonproduction earnings until after 1958, as shown in Panel A of Table 2. Moderate autocorrelation of nonproduction earnings is present in the four-digit data, but it remains much weaker than for production workers. $R^{2}$ for nonproduction eamings between 1909 and 1947 across 101 industries (Panel B of Table 2) is half as small (0.274) as that for wages of production workers $(0.550)$. There is also a substantial difference in the $R^{2}$ values for nonproduction earnings (0.547) and production wages (0.722) between 1958 and 1984 .

Although the weaker autocorrelation patterns for nonproduction workers suggest that there will be a much weaker relationship between production and nonproduction eamings before the $1960 \mathrm{~s}$, Table 3 shows a very strong correlation $\left(R^{2}=0.538\right)$ going back to 1899 . The only difference with the modern results is that the coefficient is negative! 
A more detailed examination of Table 3 shows that this is not an isolated finding. The correlation remains negative through 1929. Between 1933 and 1947, there is no significant relationship between production and nonproduction eamings. A positive correlation does not appear until the 1958 Census. The very strong correlation that has received so much attention in recent studies does not appear until 1977.

Things change when the analysis is shifted to four-digit industries. In 1909 there is a positive correlation between the wages of production workers and the earnings of nonproduction workers, but it is a fairly weak one, as shown in Panel $A$ of Table $4 . R^{2}$ for an employment-weighted regression over 101 industries is 0.127 in 1909; it increases only slightly to 0.156 by $1947 . R^{2}$ is considerably larger in both $1958(0.450)$ and $1984(0.582)$.

The correspondence of wage growth for production workers to earnings growth for nonproduction workers is quite weak. These results are reported in Panel B of Table 4. $R^{2}$ is 0.047 between 1909 and 1947 and 0.227 between 1958 and 1984. The hypothesis that the rates of change in these two variables are the same is strongly rejected by the data.

This examination of the historical record on interindustry wage differentials has yielded two important conclusions. First, the evidence that is always cited as supporting the argument that interindustry wage differentials are highly stable over time is more complex than previous studies have indicated. There is no question about the presence of autocorrelation, particularly for industries in the lowest wage decile, but the pattern for nonproduction workers is much weaker than that for production workers. Autocorrelation persists over a small sample of industries for most of the century, but there is also evidence of the type of adjustment that one would expect from the competitive model. 
Second, the appearance of interindustry wage differentials that are roughly the same for all occupational groups is a relatively recent phenomenon. This is a new and important stylized fact for researchers examining how labor market behavior has changed over the last one hundred years to explain. One possibility is that as more large companies introduced personnel departments, idiosyncratic differences in pay between production and nonproduction workers gradually vanished in many industries. Another explanation involves the spread of collective bargaining; as unions established industry patterns, firms decided to adopt those patterns for nonproduction workers. Finally, it is important to note the rising share of nonproduction workers and their changing roles within organizations. At the turn of the century, most were either hands-on managers/proprietors, whose incomes may have been sensitive to profits, or sales personnel, many of whom were paid on commission. Since then most of the growth in nonproduction jobs has been centered in professions and middle management where people tend to work on salary.

\section{Wage dispersion}

At least since Wachter (1970), the cyclical properties of wage dispersion have been well known. The trend of rising dispersion since about 1970 has been well established in a number of studies, including Montgomery and Stockton (1985), Lawrence and Lawrence (1985), and Bell and Freeman (1991). An issue that has not been addressed is how wage dispersion today compares to wage dispersion fifty to one hundred years ago. Average hourly eamings for two-digit industries have been reported by the Bureau of Labor Statistics in Employment and Eamings since 1947. Data sets reporting wages by industry for earlier 
periods include Rees (1961) for 1890-1914 and Conference Board (1946) for 1914 and 19201946. To make valid comparisons across such heterogeneous data sets, I need some anchors. The two used below are average annual eamings for full-time equivalent employees from the National Income and Product Accounts (NIPA) and the ratio of payrolls to average employment for production workers in the Census of Manufacturing. These are obviously not wage series, but their movements over time closely mirror those of the wage data, as shown in Figure 1. The measure of wage rate dispersion used here is the coefficient of variation. All calculations are weighted by employment."

Wage rate inequality across industries has followed varying trends over the last one hundred years. Between 1890 and 1920, the overall trend was toward lower inequality, although there was considerable fluctuation around that trend. Inequality increased in the 1920 s and the first third of the 1930s. After a brief decline in 1932-33, inequality in all three data sets increased again. Average inequality in the 1930s was much higher than in previous decades.

Throughout the 1940s, inequality in wages across manufacturing industries fell considerably. This is consistent with the pattem of declining wage inequality across individuals pointed out by Goldin and Margo (1992). The trough is difficult to pinpoint because the BLS series starts in 1947 just as the Conference Board series terminates. The NIPA series is the only continuous one throughout this period and it reaches its lowest level in 1947. Rees and Hamilton (1971) report a trough in that same year for 16 three-digit manufacturing industries that can be traced back to 1935 . 
Since 1950 , wage inequality across industries has been increasing. The cyclical pattem of narrowing inequality in expansions and widening inequality in contractions is apparent in the data until the 1980 s. In the 1980 s, inequality continued to widen despite the expansion. The BLS series shows a slight leveling off at the end of the decade, whereas the NIPA series shows no break in the trend.

How do the levels of wage rate inequality in manufacturing observed today compare to those observed over the last hundred years? The natural comparison to make here is to use the NIPA data for the 1980 s and compare inequality now to the peak values prevailing between 1933 and 1942 . The mean coefficient of variation for 1980-89 was 0.213 , slightly larger than the mean of 0.209 for 1933-42. Inequality in wages across manufacturing industries has never been any higher in the last one hundred years than it is today.

This does not automatically imply that wage inequality across persons is also at alltime peaks. The advantage of using data for manufacturing and no other sector is that it standardizes for type of job. The shortcoming is that it ignores wage dispersion within industries and wage dispersion between manufacturing and other sectors of the economy. However, the patterns for wage inequality across individuals between 1940 and 1985 reported by Goldin and Margo are very similar to those in Figure 1.

The fluctuating trends in wage dispersion demonstrate that despite autocorrelation, the shape of the interindustry distribution of wages changes considerably. Other than shifts in the distribution of labor quality across industries, labor economics lacks a positive model that can explain the changes in trend that took place in 1940 and 1970. 
Industry characteristics and wage growth

Previous research The modem literature linking industry characteristics and the determination of wage levels is quite vast; Dickens and Katz (1987a) summarize 22 such studies and present an impressive amount of new evidence on this issue. They found industry wages to be related to years of schooling, percentage female, profitability, establishment size, and capital intensity in 1939 and 1983 cross section equations. Katz and Summers (1989) obtained similar results.

Very few studies in recent years have examined changes in compensation by industry. Blanchflower, Oswald, and Sanfey (1992) examine year-to-year wage behavior. Lawrence and Lawrence (1985) regress wage changes on the initial levels of selected variables for a variety of short sample periods (no more than ten-year intervals) between 1960 and 1984. Although no variable is significantly related to wage growth in every period, the strongest correlates are the capital-labor ratio and the proportion of workers in large establishments. Bell and Freeman (1991) and OECD (1986) find a strong correlation between wage growth and productivity growth for a variety of postwar samples. Freeman and Katz (1991) show wage growth in manufacturing between 1958 and 1984 to be related to output growth, the growth of product prices, and the initial level and change in percentage immigrant.

Levels versus changes All estimates of interindustry wage differences are subject to the criticisms that (1) the industry effects are really unobservable firm and worker characteristics for which the researchers have failed to control and (2) the estimated relationship between wages and variables such as $R \& D$, productivity, capital intensity, concentration, and profits is biased as a result of omitting the unobserved variables. If the 
distribution of unobservables across industries is stable over time and their relationship to earnings does not change, then differencing eliminates the bias.

Another potential advantage of using wage change equations is that there could be less multicollinearity among key industry characteristics. This is an empirical issue and is addressed in Table 5. In cross sections there is a positive, and usually very strong, correlation between wages of production workers and labor productivity, capital-labor ratio $(\mathrm{K} / \mathrm{L})$, employees per establishment, percentage union, and the profit rate (estimated by using the price-cost margin). Further, there are strong cross-sectional relationships among most of the possible pairings of labor productivity, the capital-labor ratio, percentage union, and profits.

Almost without exception, the correlations among the first differences of these variables are much weaker than the cross-sectional relationships. For instance, the correlation between wages and percentage union is about 0.5 in each of the cross sections, but falls to 0.16 in first differences. The correlations between wages and both establishment size and the capital-labor ratio adjust in a similar fashion, as one would expect if unobservables were correlated with these variables. The positive correlation between wages and the profit rates actually changes signs after first differencing. The variables that potentially would be used on the right-hand side of a wage equation exhibit much more independence after furst differencing.'

The correlations of these variables with average earnings of nonproduction workers are always weaker than the correlations with wages for production workers. This is 
consistent with the evidence from Section I that wages of these two occupational groups are driven by different processes.

This study focuses on the impact of five industry variables that have been widely associated with wage levels or wage growth and are measured with acceptable precision: productivity, $K / L$, establishment size, unionism, and employment. Some commonly used measures of profits then will be introduced to the analysis. The first three columns of Table 6 report regressions of the change in log wages on the change in log productivity, $\ln (\mathrm{K} / \mathrm{L})$, employees per establishment, employment, and percentage union members for production and nonproduction workers for 1958-84. The last two columns report results for 1909-1947, excluding $\mathrm{K} / \mathrm{L}$. The results for average annual earnings of nonproduction workers are much weaker than those for production workers, as reflected in lower $R^{2}$ and smaller absolute values of coefficients.

\section{Results}

Productiviny The productivity measure used in columns 1, 4, and 5 is nominal value added divided by labor. This is problematic in two ways: (1) labor productivity automatically rises with the capital-labor ratio and (2) value added measures nominal, not real, output. Total factor productivity (TFP) growth is estimated by constructing an input growth index based on growth of the capital stock and hours, with weights being the average of the input shares in 1958 and 1984. The value of shipments deflator is used to convert nominal to real values. ${ }^{10}$ The fit of the equation declined dramatically when TFP growth replaced value-added productivity growth, indicating part of the productivity-wage 
relationship in column 1 is really a price-wage relationship. For this reason the specifications in column 2 and 3 include the log of price change as a right-hand side variable. This approach is similar to that used in Bell and Freeman (1991); the results here differ in that the sample period is longer and the model contains additional explanatory variables.

Productivity growth is strongly correlated with wage growth in all but one model estimated in Table 6. A 10 percentage point increase in the rate of TFP growth in 1958-84 is associated with a 3.2 percent increase in wages for production workers and a 2.3 percent increase for nonproduction workers. In 1909-47, there is a strong correlation between the growth of nominal, value-added productivity for production workers, but not for nonproduction workers.

Despite the strong correlation between prices and wages in columns 2 and 3 , there is no apparent causality pattern. The log change in wages (prices) was regressed on three lagged values of wage and price change. To test for Granger causality, the price (wage) coefficients were then restricted to zero and F-statistics were calculated. For production workers, wages Granger-caused price changes in 16 industries, prices caused wage changes in 28 industries, causality ran in both directions in 302 industries, and there was no causality in 104 industries. Wages were more likely to cause price changes for nonproduction workers. This pattern prevailed in 32 industries. Prices caused changes in nonproduction wages in 35 industries, causality ran in both directions in 309 industries, and there was no causality in 74 industries.

$K / L$ Wage growth in 1958-84 is much greater in industries with rising capital-labor ratios. The relationship is much stronger for production than nonproduction workers. 
Establishment size The statistically significant, positive relationship between log wage levels and establishment size for both production and nonproduction workers in the simple correlations in Table 5 was still apparent in cross section regressions for 1958 and 1984 (not reported in Table 6, but available from the author). However, just as in the simple correlations, log wage growth is unrelated to changes in average establishment size. There is a correlation between establishment size and log wage levels in 1947, but not in 1909 . Wage growth in this period is also unrelated to the change in average establishment size.

Union density A very important factor behind wage growth for production workers is the change in union density. A 10 percentage point drop in union density is associated with 1.7 to 2.7 percent decrease in wages in 1958-84. The NBER Trade and Immigration Data Set uses union density in 1973-75 as an estimate of union density in all prior years. When the model was re-estimated over the $1973-84$ period, the union coefficient was $0.202(0.085)$.

Unionization data for 1909 for four-digit industries are imputed from Whaples (1990), who developed his estimates by breaking out the assignments of union members to industries by Wolman (1936) more finely. In the cases where Whaples does not report a union density estimate, it is assumed to be zero. As a proxy for union density in 1947, the estimates by two-digit industry of Lewis (1963, p. 254) for 1953 are used." In the results reported in Table 6, a 10 percentage point increase in union density from $1909-47$ is associated with 1 percent more wage growth. The coefficient (S.E) of union density rises to $0.149(0.063)$ when a profit variable is added to the model.

Employment growh The log change in employment is included in the model because it has been examined in previous studies as a possible indicator of labor supply elasticity. 
Wages of production workers grew slightly more rapidly between 1958 and 1984 in industries with growing employment than in other industries, other things equal. However, there is no relationship between employment growth and wage growth for nonproduction workers or in the 1909-47 sample.

Profits Table 7 reports the results from three different models of the relationship between the change in profits and the change in log wages for five ratio measures of profitability: profits to output (also called the price-cost margin), profits to capital (structures and equipment), profits to employment, quasi-rents to output, and quasi-rents to employment. ${ }^{12}$ In theory profits are a function of output prices, input prices, and total factor productivity; an equation estimating the effect of profits on wages while holding output prices and productivity constant makes little sense. Model 1 uses the same specifications as in the columns 2 and 3 of Table 6 except that the coefficients of prices and productivity are restricted to zero. Although Model 1 is consistent with theory, it is not consistent with the patterns in the data in one important respect - the hypothesis that the price and productivity coefficients are zero is rejected decisively in every case. Model 2 removes these restrictions.

The results show that the correlation between the growth in profitability and the growth in log wages in manufacturing industries is sensitive to the choice of the profit variable. Among production workers, there is a strong, positive correlation between profit growth and wage growth for four of the five profit variables in Model 1 and two of the five cases in Model 2. In both models, there is a strong negative correlation between the change in the price-cost margin and wage growth. In the results for nonproduction workers, there 
was a strong positive correlation between wage and profit growth for four of the profit variables in Model 1, but for only one of the profit variables in Model 2.

Hausman tests were performed to determine whether the profit variable was correlated with the error term. To achieve identification, the change in average establishment size was omitted from the wage equation. This variable was chosen because of the absence of any correlation with wages. Of the five profit variables examined, the hypothesis that profits were uncorrelated with the error term was rejected for the price-cost margin for both production and nonproduction workers. It was not rejected for any of the other profit measures. In 2SLS estimates, reported as Model 3 in Table 10, there is a strong positive correlation between the change in the price-cost margin and wage growth.

Further evidence of a positive correlation between profits and wages is obtained using the rate of retum series created by Stigler (1963) for 1939 and 1954. He reports rank correlations with annual eamings of 0.30 for 1939 and 0.55 in 1954 . Moving to first differences of both variables, there is a positive correlation for 1939-47 and 1947-54. A one percentage point increase in rate of retum is associated with a 1.2 to 1.5 percent increase in log eamings (with a standard error of 0.4 percent); $R^{2}$ are between 0.36 and 0.37 .

Concentration ratios The NBER Trade and Immigration Data Set lacks complete information on four-firm concentration ratios. They are available for about half the industries in 1958, but for none of them in 1984. Some models examining the impact of concentration levels on wage levels and the impact of changes in concentration on wage changes were estimated for 1958 and 1973. The coefficient of the concentration ratio was never statistically significant in any specification and the coefficients of other variables were 
insensitive to its inclusion. The standard deviation of the change in the concentration ratio was 9.57 percentage points, implying that these nonresults are not being generated by insufficient variation in the right-hand variable.

Controlling for labor quality One shortcoming of the NBER data is that there are no controls for worker characteristics, especially human capital variables such as schooling and on-the-job training. Human capital is thought to be complementary with physical capital and productivity growth. Two simple procedures were used to determine whether inclusion of human capital in the empirical model is likely to affect the results.

The Census reports average years of schooling of male employees by two digit industry in 1960 and 1970; the same variable is available in BLS Special Labor Force Reports (based on the Current Population Survey) for 1970 and 1979. This information was matched with average hourly earnings of production workers for the corresponding years to examine the relationship between schooling and wages, using both levels and first differences. There is a strong correlation between schooling and wages in $1960\left(R^{2}=0.54\right)$, but by 1979 it had become much weaker $\left(R^{2}=0.25\right)$. The main reason for this is that as the inequality of earnings across industries has increased, the inequality in years of schooling has plummeted. Average years of schooling across two-digit industries increased from 10.7 to 12.5 , but the standard deviation dropped from 1.2 to 0.3 . Thus it should come as no surprise that there is no correlation between wage growth and the change in average years of schooling over this period; $\mathbf{R}^{2}$ for this equation is an appalling 0.0001 .

Second, wage equations with a set of 43 industry dummies were estimated over the May 1973-75 and 1989 full-year Current Population Survey with and without any individual 
characteristics. The regression of the industry dummies obtained when controls for human capital and demographic characteristics are included in the model on the dummies obtained without such controls had an $R^{2}$ of 0.93 in $1973-75$ and 0.96 in 1989. The inclusion of individual characteristics does affect the dispersion of interindustry wage differentials (the standard deviation shrinks from 0.29 to 0.18 in each sample) but not the ordering.

In summary, this analysis has shown that (1) the determinants of earnings in cross sections are quite different from the determinants of eamings in first differences; (2) there is a correlation between wage growth and productivity growth and the change in union density in both $1909-47$ and $1958-84$; (3) in 1958-84 wage growth is also correlated with product price inflation and capital deepening; (4) although the impact of the change in profits on the change in wages is sensitive to specification, the most reasonable estimates find a nonnegative correlation; (5) these variables do a much better job of explaining wage growth for production workers than earnings growth for nonproduction workers; and (6) the omission of human capital from the empirical model is unlikely to be a serious source of bias.

\section{Conclusion}

The determinants of wage growth by industry have received a negligible amount of attention from labor economists despite the likely implications such research would presumably have for interpreting interindustry wage differentials. The prevailing wisdom is that wage premiums are relatively constant over time, do not vary across occupations, and are most likely in industries with high productivity, high average schooling levels, low 
percentage female, high profits, large establishments, and high capital-labor ratios.

Unionization is not viewed as an important factor.

The results of this analysis are inconsistent with some of these findings. Eamings of nonproduction workers follow a completely different process than wages for production workers - they are much less autocorrelated and are much less easily explained in terms of industry characteristics. Although the ranking of industries in the distribution of wages for production workers is quite stable, especially at the lower tail, the shape of the distribution has fluctuated considerably over the years. The correlation between industry characteristics and wages is often sensitive to the use of cross section versus fixed effect estimation. Wage growth is associated with rising productivity, increased union density, higher profits, and increased capital intensity. Changes in schooling levels and establishment size are uncorrelated with wage growth. The relationship between wage growth and profits needs further study, preferably with a data set matching widely accepted measures of financial performance with wages.

The difficult question of how any results can be interpreted remains. Although many authors have interpreted the correlation between wages and productivity or capital-labor ratios as evidence of rent-sharing, these relationships also have a price theoretic interpretation. For instance, if capital and skilled labor are complements in production, it would be surprising if there were no correlation between growth in wages and the capitalLabor ratio.

Neither the competitive model nor any of its competitors is fully consistent with all of the results reported here. Industry wage differentials that persist for almost an entire century 
and are strongly correlated with prices (and frequently profits) are difficult to reconcile with the competitive approach. The different patterns for nonproduction and production workers are not what one would expect from most noncompetitive models of wage determination. The varying trends in wage dispersion across industries may reflect changing social norms.

The results of this paper raise questions about the historical evolution of American labor markets. Strong correlations between earnings of production and nonproduction workers are not apparent in the data until after the end of World War II. What changes in the organization of firms or the nature of labor markets brought about this correlation? Why do industrial pay differentials for nonproduction workers fluctuate so much more, even today, than those for production workers? Study of within-industry changes in the ratio of nonproduction to production eamings over the last century will be required to address these issues. 


\section{REFERENCES}

Abowd, John M., and Farber, Henry S., "Product-Market Competition, Union Organizing Activity, and Employer Resistance," NBER Working Paper No. 3353, May 1990.

Backman, Jules, and Gainsbrugh, M. R., Behavior of Wages (New York: National Industrial Conference Board, 1948).

Bell, Linda, and Freeman, Richard, "The Causes of Rising Interindustry Wage Dispersion in the United States, "Industrial and Labor Relations Review 44 (January 1991): 275287.

Blackburn, McKinley, and Neumark, David, "Unobserved Ability, Efficiency Wages, and Interindustry Wage Differentials," Quarterly Joumal of Economics 107 (November 1992): $1421-1436$.

Blanchflower, David G., Oswald, Andrew J., and Sanfey, Peter, "Wages, Profits, and RentSharing," NBER Working Paper No. 4222, December 1992.

Carmichael, H. Lome, "Efficiency Wage Models of Unemployment - One View," Economic Inquiry 28 (April 1990): 269-295.

Conference Board, Economic Almanac for $1946-47$ (New York: National Industrial Conference Board, 1946).

Creamer, Daniel; Dobrovolsky, Sergei; and Borenstein, Israel, Capital in Manufacturing and Mining (Princeton: Princeton University Press for the National Bureau of Economic Research, 1960). 
Cullen, Donald, "The Interindustry Wage Structure: 1899-1950," American Economic

Review 46 (June 1956): 353-369.

Dickens, William T., and Katz, Lawrence F., "Inter-Industry Wage Differences and Industry Characteristics," in Kevin Lang and Jonathan Leonard (eds.), Unemployment and the Structure of Labor Markets (New York: Basil Blackwell, 1987a). , "Inter-Industry Wage Differences and Industry Characteristics," NBER Working Paper No. 2271, June 1987b.

Dunlop, John T., "Productivity and the Wage Structure," in Income. Employment. and Public Policy (New York: W. W. Norton, 1948).

Freeman, Richard B., and Katz, Lawrence F., "Industrial Wage and Employment Determination in an Open Economy," in John Abowd and Richard Freeman (eds.), Immigration. Trade, and the Labor Market (Chicago: University of Chicago Press, 1991).

Garbarino, Joseph W., "A Theory of Interindustry Wage Structure Variation, " Quarterly Journal of Economics 64 (May 1950): 282-305.

Gibbons, Robert, and Katz, Lawrence, "Does Unmeasured Ability Explain Inter-industry Wage Differences?" Review of Economic Studies 59 (July 1992): 515-536.

Goldin, Claudia, and Margo, Robert, "The Great Compression: The Wage Structure inthe United States at Mid-Century," Quarterly Joumal of Economics 107 (February 1992): $1-34$.

Helwege, Jean, "Sectoral Shifts and Interindustry Wage Differentials," Ioumal of Labor Economics 10 (January 1992): 55-84. 
Katz, Lawrence F., and Summers, Lawrence, "Industry Rents: Evidence and Implications," Brookings Papers on Economic Activity: Microeconomics 1989: 209-275.

Keat, Paul G., "Long-Run Changes in Occupational Wage Structure, 1900-1956," Joumal of Political Economy 68 (December 1960): 584-600.

Kendrick, John W., Productivity Trends in the United States (Princeton: Princeton University Press for the National Bureau of Economic Research, 1961).

Krueger, Alan B., and Summers, Lawrence H., "Reflections on the Inter-Industry Wage Structure," in Kevin Lang and Jonathan Leonard (eds.), Unemployment and the Structure of Labor Markets (New York: Basil Blackwell, 1987). , "Efficiency Wages and the Inter-Industry Wage Structure," Econometrica 56 (March 1988): 259-293.

Lang, Kevin, and Kahn, Shulamit, "Efficiency Wage Models of Unemployment: A Second View," Economic Inquiry 28 (April 1990): 296-306.

Lawrence, Colin, and Lawrence, Robert Z., "Manufacturing Wage Dispersion: An End Game Interpretation," Brookings Papers on Economic Activity 1985: 47-116.

Lewis, H. Gregg, Unionism and Relative Wages in the United States (Chicago: University of Chicago Press, 1963).

Meyers, Frederic, and Bowlby, Roger L., "The Interindustry Wage Structure and Productivity," Industrial and Labor Relations Review 7 (October 1953): 93-102. Montgomery, Edward, and Stockton, David J., 'Evidence on the Causes of the Rising Dispersion of Relative Wages," Board of Governors of the Federal Reserve System Working Paper No. 49, May 1985. 
Murphy, Kevin M., and Topel, Robert H., "Unemployment, Risk, and Earnings: Testing for Equalizing Wage Differences in the Labor Market, " in Kevin Lang and Jonathan Leonard (eds.), Unemployment and the Structure of Labor Markets (New York: Basil Blackwell, 1987).

OECD, Wages and Labour Mobility (Paris: OECD, 1965). Elexibility in the Labour Market (Paris: OECD, 1986).

Reder, Melvin W., "Wage Structure Theory and Measurement," in Universities-National Bureau Committee for Economic Research, Aspects of Labor Economics (Princeton: Princeton University Press for the National Bureau of Economic Research, 1962). Rees, Albert, Real Wages in Manufacturing 1890-1914 (Princeton: Princeton University Press, 1961).

Rees, Albert, and Hamilton, Mary T., "Changes in Wage Dispersion," in John F. Burton, Jr.; Lee K. Benham; William M. Vaughn, III; and Robert J. Flanagan (eds.), Readings in Labor Market Analysis (New York: Holt, Rinehart and Winston, 1971). Reynolds, Lloyd G., and Taft, Cynthia H., The Evolution of Wage Structure (New Haven: Yale University Press, 1956).

Ross, Arthur M, and Goldner, Williarn, "Forces Affecting the Interindustry Wage Structure," Quarterly Joumal of Economics 64 (May 1950): 254-281.

Salter, W. E. G., Productivity and Technical Change, 2nd ed., (Cambridge: Cambridge University Press, 1960).

Slichter, Sumner H., "Notes on the Structure of Wages," Review of Economics and Statistics 32 (February 1950): 80-91. 
Solon, Gary R., "Intergenerational Income Mobility in the United States," American Economic Review 82 (June 1992): 393-408.

Stigler, George J., Capital and Rates of Retum in Manufacturing Industries (Princeton:

Princeton University Press for the National Bureau of Economic Research, 1963).

Thaler, Richard H., "Anomalies: Interindustry Wage Differentials," Joumal of Economic Perspectives 3 (Spring 1989): 181-193.

Topel, Robert H., "Comment on Katz and Summers," Brookings Papers on Economic Activity: Microeconomics 1989: 283-288.

U.S. Bureau of the Census, Historical Statistics of the United States. Colonial Times to 1970 (Washington: Government Printing Office, 1975).

Wachter, Michael, "Cyclical Variation in the Interindustry Wage Structure," American Economic Review 60 (March 1970): 75-84.

Weiss, Andrew, Efficiency Wages (Princeton: Princeton University Press, 1990).

Whaples, Robert, "The Shortening of the American Work Week: An Economic and Historical Analysis of its Context, Causes, and Consequences," $\mathrm{Ph} . \mathrm{D}$. dissertation, University of Pennsylvania, 1990.

Wolman, Leo, Ebb and Flow in Trade Unionism (New York: National Bureau of Economic Research, 1936). 
1.These studies include Dickens and Katz (1987a, 1987b), Helwege (1992), Katz and Summers (1989), and Krueger and Summers $(1987,1988)$.

2.For more details see Murphy and Topel (1987) and Topel (1989). A balanced assessment of the empirical and theoretical issues appears in Thaler (1989). Theoretical considerations are examined more thoroughly in Weiss (1990) and the exchange between Carmichael (1990) and Lang and Kahn (1990). Gibbons and Katz (1992) and Blackbum and Neumark (1992) empirically attempt to deal with the unobserved-ability issue.

3.It is impossible to say how generalizable the results of this study are outside of manufacturing. Differentials in income for full-time equivalent workers between manufacturing and other industries fluctuate modestly. Income in manufacturing varies between 4 to 14 percent above income for the economy as a whole from 1930 and 1990. However, the ratio of income in manufacturing to income in some one-digit industries (e.g., transportation, finance, and wholesale and retail trade) varies to a much greater extent over this period.

4.The Census data are reported in U.S. Bureau of the Census (1975), series P58-P67 on pp. 669-680. The Conference Board data are reported in Conference Board (1946), pp. 178-9. The BLS data come from CITIBASE. The BLS data also were used to transform Kendrick's (1961, p. 197) wage index data into wage rate data.

5.Solon (1992) demonstrates that the regression coefficient and $R$, the square root of the $R^{2}$ statistic, are both consistent estimators of autocorrelation, as long as the standard deviation of log wages is the same at the start and the end of the period. When the latter assumption does not hold, the regression coefficient estimates the product of autocorrelation and the ratio of the standard deviation of wages at the end to the standard deviation of wages at the beginning of the . 
period. In three of the samples, this standard deviation changes considerably, rising from 0.142 in 1899 to 0.180 in 1947 in the Census data, falling from 0.200 in 1914 to 0.132 in 1946 in the Conference Board data, and rising from 0.132 in 1947 to 0.254 in 1988 in the BLS data.

6.Slichter's results hold up to a number of other potential criticisms besides failure to weight by employment. They are robust over an even longer time period and if one considers both silled and unskilled production workers, as shown by Keat (1960). They also are insensitive to disaggregation (Cullen (1956), Reynolds and Taft (1956, p. 337)) and robust across different countries (OECD (1965, p. 23)). The only contrarian in this early literature is Reder (1962, p. 281), who reports a rank correlation of 0.46 between 1899-1909 and 1948-53 for all 33 industries in Kendrick (1961, p. 197). The findings of four recent studies also are supportive: Montgomery and Stockton (1985), Krueger and Summers (1987, 1988), and Helwege (1992). 7.The data are reported in U.S. Bureau of the Census (1975), pp. 669-680.

8.Industry definitions in the Rees and Conference Board data are not the same as those used by the Bureau of Labor Statistics or NIPA. The coverage is also more narrow in the Rees and Conference Board series.

9.The decrease in the correlations as one moves from cross sections to first differences could be caused by greater measurement error, rather than by increased independence among the righthand variables and removal of unobservables. To test this I compared the autocorrelations of productivity, K/L, employees per establishment, and various profitability measures for censal and intercensal years. Data for pairs of intercensal years are based on a considerably smaller sample and should exhibit lower autocorrelation than for pairs of censal years if measurement 
error is a serious problem. No such patterns were detected in the data. Further details are available from the author upon request.

10.Estimates of capital growth and price change for two and three digit industries from Creamer et al. were examined for the prewar period; both were unrelated to wage growth and its inclusion had no notable impact on the other coefficients.

11.Lewis' estimates for 1929 were also examined as possible proxies for union density in 1909 , but these results are not reported because the standard enrors were much larger than those obtained from Whaples' variable.

12. Quasi-rents are estimated by subtracting opportunity eamings instead of payroll from output when calculating profits. Opportunity earnings equal the product of the opportunity wage index from Abowd and Farber (1990), hours worked, and average hourly eamings for all manufacturing industries. 
Table 1. Estimates of autocorrelation of the interindustry wage structure, production workers in manufacturing

\begin{tabular}{llcccc}
\hline $\begin{array}{c}\text { Variable } \\
\text { and source }\end{array}$ & $\begin{array}{c}\text { Constant } \\
\text { (S.E.) }\end{array}$ & $\begin{array}{c}\text { Coefficient } \\
\text { (S.E.) }\end{array}$ & $R^{2}$ & $N$ \\
\hline
\end{tabular}

A. Two-digit industries, unweighted by employment

$1899-1953$

$1899-1947$

$1914-1946$

$1947-1988$

verage hourly earnings; BLS

B. Two-digit industries, weighted by employment

\begin{tabular}{|c|c|c|c|c|c|}
\hline $1899-1953$ & $\begin{array}{l}\text { Average hourly } \\
\text { earnings; Kendrick }\end{array}$ & $\begin{array}{c}1.931 \\
(0.296)\end{array}$ & $\begin{array}{c}0.746 \\
(0.158)\end{array}$ & 0.553 & 20 \\
\hline $1899-1947$ & $\begin{array}{l}\text { Average annual } \\
\text { earnings; Census }\end{array}$ & $\begin{array}{c}1.443 \\
(0.209)\end{array}$ & $\begin{array}{c}0.642 \\
(0.218)\end{array}$ & 0.420 & 14 \\
\hline $1914-1946$ & $\begin{array}{l}\text { Average bourly earnings; } \\
\text { Conference Board }\end{array}$ & $\begin{array}{c}3.535 \\
(0.520)\end{array}$ & $\begin{array}{c}0.634 \\
(0.095)\end{array}$ & 0.701 & 21 \\
\hline $1947-1988$ & $\begin{array}{l}\text { Average hourly } \\
\text { earnings; BLS }\end{array}$ & $\begin{array}{c}2.018 \\
(0.079)\end{array}$ & $\begin{array}{c}1.295 \\
(0.342)\end{array}$ & 0.444 & 20 \\
\hline \multicolumn{6}{|c|}{ C. Four-digit industries, weighted by employment } \\
\hline $1909-47$ & $\begin{array}{l}\text { Average anmual } \\
\text { earnings; Census }\end{array}$ & $\begin{array}{c}1.232 \\
(0.092)\end{array}$ & $\begin{array}{c}0.594 \\
(0.054)\end{array}$ & 0.550 & 101 \\
\hline $1958-84$ & $\begin{array}{l}\text { Average annual } \\
\text { earnings; Census }\end{array}$ & $\begin{array}{c}1.360 \\
(0.026)\end{array}$ & $\begin{array}{c}1.106 \\
(0.032)\end{array}$ & 0.722 & 450 \\
\hline
\end{tabular}

$\begin{array}{lcccc}\begin{array}{l}\text { Average hourly } \\ \text { earnings; Kendrick }\end{array} & \begin{array}{c}1.277 \\ (0.365)\end{array} & \begin{array}{c}0.402 \\ (0.194)\end{array} & 0.192 & 20 \\ & 1.605 & 0.806 & 0.406 & 14 \\ \begin{array}{l}\text { Average annual } \\ \text { earnings; Census }\end{array} & (0.256) & (0.282) & & \\ & & & & \\ \text { Average hourly earnings; } & 4.147 & 0.525 & 0.631 & 21 \\ \text { Conference Board } & (0.504) & (0.092) & & \\ \text { Average hourly } & 2.143 & 0.822 & 0.185 & 20 \\ \text { earnings; BLS } & (0.091) & (0.407) & & \end{array}$


Table 2. Employment-weighted estimates of autocorrelation of the interindustry wage structure, nonproduction workers in manufacturing

\begin{tabular}{lcccc}
\hline & Constant & Coefficient & \\
Years & (S.E.) & $\mathbf{R}^{2}$ & $\mathrm{~N}$ \\
& & & \\
\hline
\end{tabular}

A. Two-digit industries

$\begin{array}{lcccc}1899-1947 & 1.366 & 0.199 & 0.149 & 12 \\ & (0.032) & (0.150) & & \\ 1947-58 & 0.885 & 0.706 & 0.274 & 20 \\ & (0.373) & (0.271) & & \\ 1899-1958 & 1.846 & 0.030 & 0.005 & \\ & (0.029) & (0.132) & & 20 \\ 1947-87 & 2.587 & 0.633 & 0.122 & \\ & (0.550) & (0.400) & & 20 \\ 1958-87 & 1.258 & 1.181 & 0.801 & \end{array}$

B. Four-digit industries

$\begin{array}{ccccc}1909-47 & 5.313 & 0.419 & 0.274 & 101 \\ & (0.487) & (0.069) & & \\ 1958-84 & 1.607 & 0.881 & 0.547 & 450\end{array}$


Table 3. Estimates of correlation between average annual earnings of production and nonproduction workers in manufacturing, selected years between 1899 and 1987

\begin{tabular}{|c|c|c|c|c|}
\hline Year & $\begin{array}{l}\text { Constant } \\
\text { (S.E.) }\end{array}$ & $\begin{array}{l}\text { Coefficient } \\
\text { (S.E.) }\end{array}$ & $\mathbf{R}^{2}$ & $\mathbf{N}$ \\
\hline 1899 & $\begin{array}{l}-0.864 \\
(0.045)\end{array}$ & $\begin{array}{l}-0.621 \\
(0.182)\end{array}$ & 0.538 & 12 \\
\hline 1914 & $\begin{array}{l}-0.558 \\
(0.051)\end{array}$ & $\begin{array}{l}-0.376 \\
(0.150)\end{array}$ & 0.344 & 14 \\
\hline 1919 & $\begin{array}{c}0.389 \\
(0.116)\end{array}$ & $\begin{array}{l}-0.482 \\
(0.147)\end{array}$ & 0.472 & 14 \\
\hline 1929 & $\begin{array}{c}1.045 \\
(0.415)\end{array}$ & $\begin{array}{l}-0.899 \\
(0.423)\end{array}$ & 0.273 & 14 \\
\hline 1933 & $\begin{array}{l}-0.423 \\
(0.351)\end{array}$ & $\begin{array}{c}0.621 \\
(0.686)\end{array}$ & 0.084 & 11 \\
\hline 1935 & $\begin{array}{c}0.221 \\
(0.563)\end{array}$ & $\begin{array}{l}-0.357 \\
(0.741)\end{array}$ & 0.021 & 13 \\
\hline 1947 & $\begin{array}{c}1.500 \\
(0.525)\end{array}$ & $\begin{array}{l}-0.407 \\
(0.374)\end{array}$ & 0.062 & 20 \\
\hline 1958 & $\begin{array}{l}-0.879 \\
(0.556)\end{array}$ & $\begin{array}{c}1.249 \\
(0.299)\end{array}$ & 0.492 & 20 \\
\hline 1967 & $\begin{array}{c}-1.220 \\
(0.790)\end{array}$ & $\begin{array}{c}1.344 \\
(0.357)\end{array}$ & 0.440 & 20 \\
\hline 1977 & $\begin{array}{l}-2.295 \\
(0.696)\end{array}$ & $\begin{array}{c}1.655 \\
(0.244)\end{array}$ & 0.719 & 20 \\
\hline 1987 & $\begin{array}{l}-1.895 \\
(0.684)\end{array}$ & $\begin{array}{c}1.423 \\
(0.198)\end{array}$ & 0.741 & 20 \\
\hline
\end{tabular}

Note: The dependent variable is the log of average annual earnings for production workers. Each equation is weighted by employment. 
Table 4. Relationship between wages of production workers and earnings of nonproduction workers, four-digit industries in manufacturing

\begin{tabular}{lcccc}
\hline Sample & $\begin{array}{c}\text { Constant } \\
\text { (S.E.) }\end{array}$ & $\begin{array}{c}\text { Coefficient } \\
\text { (S.E.) }\end{array}$ & $\mathbf{R}^{2}$ & $\mathrm{~N}$ \\
\hline
\end{tabular}

A. Regressions of production wages on nouproduction earnings

\begin{tabular}{|c|c|c|c|c|}
\hline 1909 & $\begin{array}{l}-4.635 \\
(0.772)\end{array}$ & $\begin{array}{c}0.410 \\
(0.108)\end{array}$ & 0.127 & \\
\hline 1947 & $\begin{array}{l}-4.178 \\
(1.029)\end{array}$ & $\begin{array}{c}0.531 \\
(0.124)\end{array}$ & 0.156 & \\
\hline 1958 & $\begin{array}{l}-0.302 \\
(0.057)\end{array}$ & $\begin{array}{c}0.926 \\
(0.048)\end{array}$ & 0.450 & \\
\hline 1984 & $\begin{array}{l}-0.762 \\
(0.119)\end{array}$ & $\begin{array}{c}1.129 \\
(0.045)\end{array}$ & 0.582 & \\
\hline & \multicolumn{4}{|c|}{$\begin{array}{l}\text { B. Regressions of change in production wages } \\
\text { on change in nonproduction earnings }\end{array}$} \\
\hline $1909-47$ & $\begin{array}{l}1.695 \\
(0.101)\end{array}$ & $\begin{array}{c}0.183 \\
(0.083)\end{array}$ & 0.047 & \\
\hline $1958-84$ & $\begin{array}{c}0.694 \\
(0.066)\end{array}$ & $\begin{array}{c}0.512 \\
(0.045)\end{array}$ & 0.227 & \\
\hline
\end{tabular}


Table 5. Correlations among wages and industry characteristics, 1958-84.

\begin{tabular}{|c|c|c|c|c|c|c|}
\hline & $\begin{array}{l}\text { Log wage } \\
\text { production } \\
\text { workers }\end{array}$ & $\begin{array}{l}\text { Log earnings, } \\
\text { nonproduction } \\
\text { workers }\end{array}$ & $\begin{array}{c}\log \\
(Y / L)\end{array}$ & $\begin{array}{l}\log \\
(K / L)\end{array}$ & Size & Union \\
\hline $\log (Y / L)$ & $\begin{array}{l}.577 \\
(.732) \\
{[.650]}\end{array}$ & $\begin{array}{l}.336 \\
(.531) \\
{[.432]}\end{array}$ & & & & \\
\hline $\log (K \Omega)$ & $\begin{array}{l}.149 \\
(.711) \\
{[.458]}\end{array}$ & $\begin{array}{c}.027 \\
(.468) \\
{[.248]}\end{array}$ & $\begin{array}{l}.061 \\
(.648) \\
{[.609]}\end{array}$ & & - & - \\
\hline Size & $\begin{array}{l}.051 \\
(.274) \\
{[.172]}\end{array}$ & $\begin{array}{l}-.055 \\
(.206) \\
{[.124]}\end{array}$ & $\begin{array}{l}.035 \\
(.173) \\
{[130]}\end{array}$ & $\begin{array}{l}-.083 \\
(.127) \\
{[.061]}\end{array}$ & & - \\
\hline Union & $\begin{array}{l}.162 \\
(.530) \\
{[.482]}\end{array}$ & $\begin{array}{l}.056 \\
(.397) \\
{[.285]}\end{array}$ & $\begin{array}{l}.158 \\
(.380) \\
{[.384]}\end{array}$ & $\begin{array}{c}.106 \\
(.383) \\
{[.378]}\end{array}$ & $\begin{array}{l}-.007 \\
(.151) \\
{[.143]}\end{array}$ & - \\
\hline $\begin{array}{l}\text { Price-cost } \\
\text { margin }\end{array}$ & $\begin{array}{l}-.143 \\
(.088) \\
{[.250]}\end{array}$ & $\begin{array}{l}-.076 \\
(.072) \\
{[.156]}\end{array}$ & $\begin{array}{l}.482 \\
(.421) \\
{[.587]}\end{array}$ & $\begin{array}{l}-.031 \\
(.335) \\
{[.237]}\end{array}$ & $\begin{array}{l}.081 \\
(.102) \\
{[.036]}\end{array}$ & $\begin{array}{c}.050 \\
-.071] \\
{[.070]}\end{array}$ \\
\hline
\end{tabular}

Note: The first term in each cell is the correlation for changes in the associated variables between 1958 and 1984; the term in parenthesis is the correlation for 1984; the term in brackets is the correlation for 1958 . The correlations are estimated over 450 four-digit industries; they are unweighted.

Source: NBER Trade and Immigration Data Set. 
Table 6. Estimates of change in log wage equations, 1909-47 and 1958-84

\begin{tabular}{|c|c|c|c|c|c|}
\hline & $\begin{array}{c}(1) \\
1958-84\end{array}$ & $\begin{array}{c}(2) \\
1958-84\end{array}$ & $\begin{array}{c}(3) \\
1958-84\end{array}$ & $\begin{array}{c}(4) \\
1909-47\end{array}$ & $\begin{array}{c}(5) \\
1909-47\end{array}$ \\
\hline $\begin{array}{l}\text { Occupation ( } \mathrm{P}=\text { production; } \\
\mathrm{N}=\text { nonproduction) }\end{array}$ & $\mathbf{P}$ & $\mathbf{P}$ & $\mathbf{N}$ & $\mathbf{P}$ & $\mathbf{N}$ \\
\hline Constant & $\begin{array}{c}0.764 \\
(0.050)\end{array}$ & $\begin{array}{c}0.694 \\
(0.062)\end{array}$ & $\begin{array}{c}0.994 \\
(0.080)\end{array}$ & $\begin{array}{c}1.289 \\
(0.078)\end{array}$ & $\begin{array}{c}1.135 \\
(0.111)\end{array}$ \\
\hline $\begin{array}{l}\text { Labor productivity } \\
\text { growth }\end{array}$ & $\begin{array}{c}0.388 \\
(0.027)\end{array}$ & & & $\begin{array}{r}0.394 \\
(0.053)\end{array}$ & $\begin{array}{c}0.067 \\
(0.076)\end{array}$ \\
\hline $\begin{array}{l}\text { Real TFP } \\
\text { growth }\end{array}$ & & $\begin{array}{c}0.324 \\
(0.030)\end{array}$ & $\begin{array}{c}0.234 \\
(0.039)\end{array}$ & & \\
\hline $\begin{array}{l}\text { Log change } \\
\text { in prices }\end{array}$ & & $\begin{array}{c}0.496 \\
(0.040)\end{array}$ & $\begin{array}{c}0.295 \\
(0.052)\end{array}$ & & \\
\hline $\begin{array}{l}\text { Log change } \\
\text { in } \mathrm{K} / \mathrm{L}\end{array}$ & $\begin{array}{c}0.032 \\
(0.011)\end{array}$ & $\begin{array}{c}0.210 \\
(0.018)\end{array}$ & $\begin{array}{c}0.113 \\
(0.023)\end{array}$ & & \\
\hline $\begin{array}{l}\text { Change in employees } \\
\text { per establishment }\end{array}$ & $\begin{array}{c}0.022 \\
(0.026)\end{array}$ & $\begin{array}{c}0.040 \\
(0.028)\end{array}$ & $\begin{array}{l}-0.020 \\
(0.036)\end{array}$ & $\begin{array}{c}0.099 \\
(0.088)\end{array}$ & $\begin{array}{l}-0.145 \\
(0.126)\end{array}$ \\
\hline $\begin{array}{l}\text { Change in } \\
\text { union density }\end{array}$ & $\begin{array}{c}0.177 \\
(0.107)\end{array}$ & $\begin{array}{c}0.272 \\
(0.110)\end{array}$ & $\begin{array}{l}0.009 \\
(0.154)\end{array}$ & $\begin{array}{c}0.100 \\
(0.086)\end{array}$ & $\begin{array}{l}-0.031 \\
(0.120)\end{array}$ \\
\hline $\begin{array}{l}\text { Log change in } \\
\text { employment }\end{array}$ & $\begin{array}{c}0.009 \\
(0.011)\end{array}$ & $\begin{array}{c}0.024 \\
(0.011)\end{array}$ & $\begin{array}{l}-0.031 \\
(0.014)\end{array}$ & $\begin{array}{l}-0.009 \\
(0.021)\end{array}$ & $\begin{array}{l}-0.010 \\
(0.027)\end{array}$ \\
\hline $\begin{array}{l}\text { Root MSE } \\
\mathrm{R}^{2}\end{array}$ & $\begin{array}{l}0.138 \\
0.353\end{array}$ & $\begin{array}{l}0.143 \\
0.306\end{array}$ & $\begin{array}{l}0.189 \\
0.090\end{array}$ & $\begin{array}{l}0.160 \\
0.400\end{array}$ & $\begin{array}{l}0.227 \\
0.025\end{array}$ \\
\hline
\end{tabular}

Source: NBER Trade and Immigration Data Set and 1909, 1947 Censuses of Manufacturing 
Table 7. Coefficients of profit variables in change in log wage equations, 1958-84

\section{PROFIT MEASURE}

$$
\begin{array}{cl}
\text { Price-cost } & \begin{array}{l}
\text { Quasi-rents Profits } \\
\text { margin }
\end{array} \text { + output }+ \text { capital }+ \text { employment }
\end{array}
$$

Model 1: OLS; prices and productivity excluded

$\begin{array}{lccccc}\text { Production } & -0.370 & 0.584 & 0.0171 & 0.0040 & 0.0044 \\ & (0.107) & (0.094) & (0.0037) & (0.0004) & (0.0003) \\ \text { Nonproduction } & -0.174 & 0.532 & 0.0111 & 0.0021 & 0.0025 \\ & (0.127) & (0.113) & (0.0044) & (0.0005) & (0.0004)\end{array}$

Model 2: OLS; prices and productivity included

$\begin{array}{llcccc}\text { Production } & -1.289 & -0.182 & 0.0056 & 0.0020 & 0.0030 \\ & (0.097) & (0.129) & (0.0034) & (0.0004) & (0.0004) \\ \text { Nonproduction } & -0.831 & 0.102 & 0.0032 & 0.0005 & 0.0013 \\ & (0.145) & (0.169) & (0.0045) & (0.0006) & (0.0006)\end{array}$

Model 3: 2SLS

$\begin{array}{lccccc}\text { Production } & 1.435 & 1.140 & 0.130 & 0.0074 & 0.0066 \\ & (0.236) & (0.128) & (0.021) & (0.0007) & (0.0006) \\ \text { Nonproduction } & 1.140 & 0.858 & 0.086 & 0.0050 & 0.0044 \\ & (0.246) & (0.151) & (0.018) & (0.0008) & (0.0007)\end{array}$

Note: Standard errors appear in parentheses. Each equation contains an intercept, the change in the capital-labor ratio, the change in average establishment size, the change in log employment, and the change in percentage union. Model 2 also contains the change in log prices and total factor productivity growth.

Source: NBER Trade and Immigration Daca Set. 


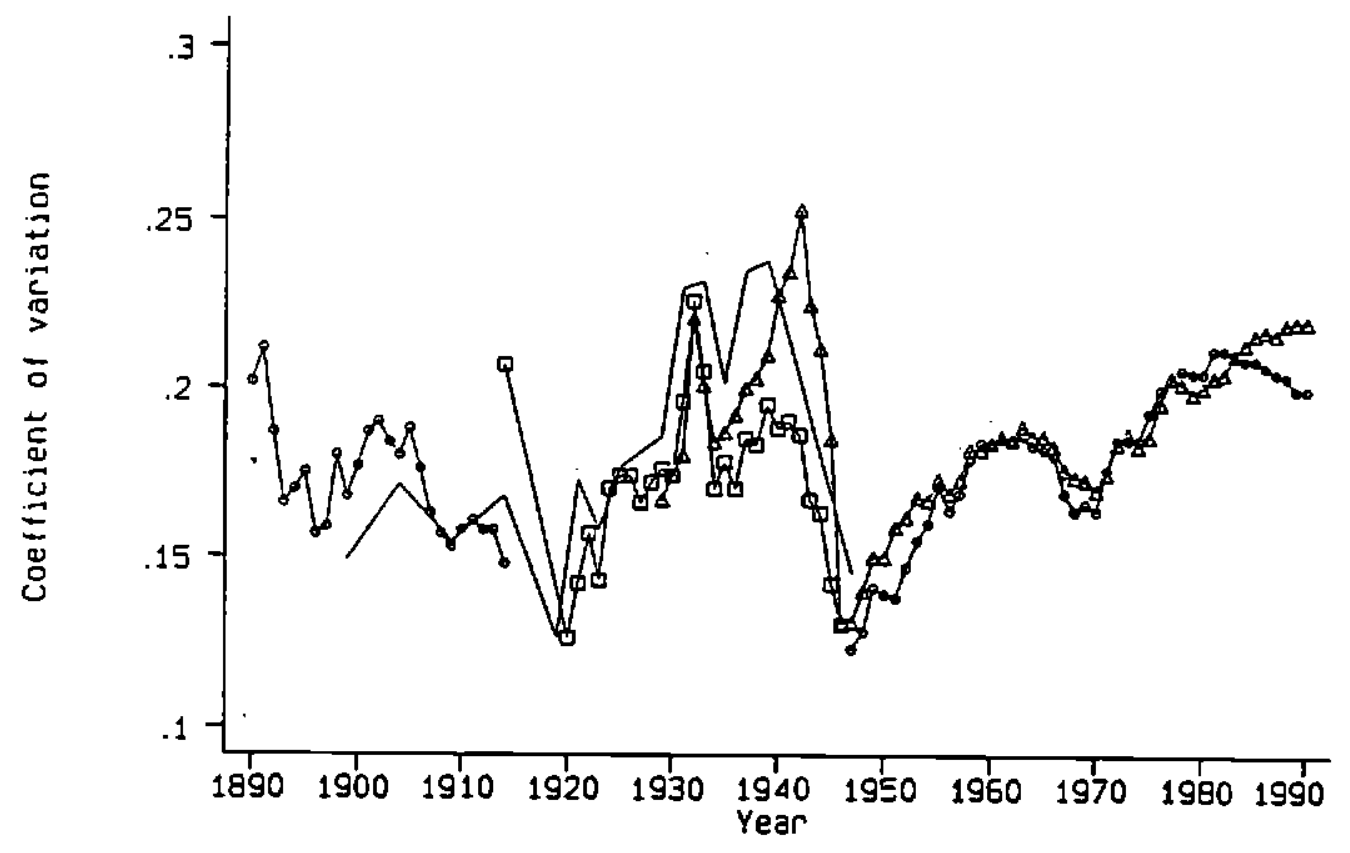

Figure 1. Wage dispersion in manufacturing, 1890-1990.

Sources: 1890-1914: Rees (1961); 1899-1947: Census of Manufacturing; 1914-1946: Conference Board; 1929-1990: National Income and Product Accounts; 1947-1990: Bureau of Labor Statistics 